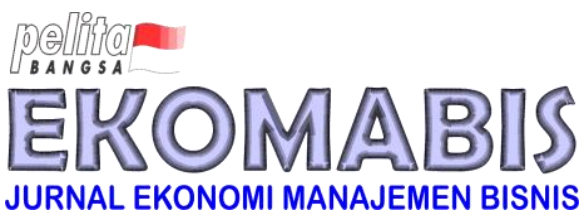

\title{
Faktor Yang Mempengaruhi Keputusan Pembelian Melalui Kepercayaan Sebagai Variabel Intervening Pada Marketplace Tokopedia
}

\section{(Factors Affecting Purchase Decisions Through Trust As Intervening Variables In Marketplace Tokopedia)}

\begin{tabular}{|c|c|c|}
\hline Submit: 12 Jun 2021 & Review: 26 Jun 2021 & Accepted: 04 Jul 2021 \\
\hline
\end{tabular}

\author{
Ratno Wijaya Kusuma1; Tio Go Ban²; Robert Yan³; Muhamad \\ Guntur $^{4}$
}

\begin{abstract}
Abstrak
Penelitian ini dilatarbelakangi oleh pertumbuhan bisnis online yang terus maju pesat di era modern saat ini ditandai dengan banyak munculnya pesaing-pesaing baru di dunia bisnis oline (Marketplace). Tujuan penelitian ini untuk mengetahui seberapa pengaruhnya tingkat persepsi promosi, kualitas informasi, dan keragaman produk melalui kepercayaan terhadap keputusan pembelian. Metode yang digunakan dalam penelitian ini adalah kuantitaf untuk populasi dan sample adalah pengguna aplikasi Tokopedia di kabupaten Bekasi dengan jumlah sampel 106 responden dan untuk analisisnya menggunakan metode Structural Equation Modeling (SEM) yang berbasis varians yaitu Partial Least Square (PLS). Hasil menunjukan bahwa variabel kepercayaan dapat memediasi persepsi promosi dan kualitas informasi dengan hasil yang positif dan signifikan terhadap keputusan pembelian.
\end{abstract}

Kata Kunci: Persepsi Promosi, Kualitas Informasi, Keragaman Produk, Keputusan Pembelian

\begin{abstract}
This research is motivated by the rapid growth of online businesses in the modern era today is characterized by many new competitors in the business world oline (Marketplace). The purpose of this study is to find out how influential the level of perception of promotion, quality of information, and diversity of products through trust in purchasing decisions. The method used in this study is quantifiable for the population and the sample is a tokopedia application user in Bekasi district with a sample number of 106 respondents and for its analysis using the variance-based Structural Equation Modeling (SEM) method, Partial Least Square (PLS). The results show that trust variables can mediate the perception of
\end{abstract}

1 "Prodi Magister Manajemen Universitas Pelita Bangsa", Ratnowijayakusuma@gmail.com

2 "Prodi Magister Manajemen Universitas Pelita Bangsa", 453n967@gmail.com

3 "Prodi Magister Manajemen Universitas Pelita Bangsa", Robby0306@gmail.com

4 "Prodi Magister Manajemen Universitas Pelita Bangsa", Muhamadguntur@pelitabangsa.ac.id 
promotion and quality of information with positive and significant results on purchasing decisions.

Keywords: Promotion Perception, Information Quality, Product Diversity, Purchasing Decisions

Kode JEL:

\section{Pendahuluan}

Perkembangan teknologi informasi sangatlah pesat dan maju. Beberapa aspek kehidupan merasakan dari dampaknya perkembangan teknologi saat ini. Beberapa aspek bidang seperti transportasi, toko online, pendidikan, dan bidang lainnya yang saat ini kita dapat merasakan dari teknologi tersebut (www.akseleran.co.id, 2020) Internet saat ini tidak hanya untuk digunakan sebagai alat dalam berkomunikasi melalui media sosial tetapi juga digunakan untuk menciptakan sebuah dunia ekonomi baru yang dapat dimanfaatkan oleh semua orang, tanpa terkecuali, didunia bisnis juga mengalami dampaknya dari perkembangan teknologi saat ini. Internet saat ini dapat dijadikan pasar potensial untuk meningkatkan omzet penjualan untuk para pelaku bisnis. Dimana penggunaan internet sudah tidak asing lagi di masyarakat khususnya saat ini. Jangkauan internet yang luas dapat dimanfaatkan oleh para pebisnis untuk media pemasaran dan untuk memperkenalkan produk-produknya kepada masyarakat dikarenakan pengguna internet disetiap tahunnnya selalu mengalami peningkatan yang signifikan baik di Indonesia maupun seluruh dunia (Jurnal.id, 2019).

Pengguna internet di Indonesia mencapai 202,6 juta jiwa pada awal tahun 2021 atau meningkat 15,5 persen dibandingkan dengan data pada januari 2020. Artinya penetrasi internet di Indonesia mencapai 73,7 persen. Layanan digital memiliki banyak keunggulan dan sangat membantu dalam kegiatan transaksi bisnis, baik itu pemasaran produk maupun jasa secara elektronik / e-commerce (www.tekno.kompas.com, 2021)

Tabel 1. Marketplace Terbaik di Indonesia Awal Tahun 2021

\begin{tabular}{lcc}
\hline \multicolumn{1}{c}{ Marketplace } & Data Pengunjung & Total Traffic Share \\
\hline Tokopedia & 129,1 Juta & $32,04 \%$ \\
Shopee & 120 Juta & $29,78 \%$ \\
Bukalapak & 33,16 Juta & $21,30 \%$ \\
Lazada & 28,66 juta & $7,11 \%$ \\
Blibi & 16,99 Juta & $4,22 \%$ \\
\hline
\end{tabular}

(www, inet.detik.com, 2021)

Keputusan pembelian adalah beberapa alternatif yang dapat dijadikan dasar bagi konsumen dalam membeli suatu produk (Schiffman \& Kanuk, 2010). Hal ini juga ditekankan oleh penelitian sebelumnya terkait keputusan pembelian (Rahmawati \& Nikmah, 2019). Konsumen membuat keputusan karena penerapan strategi diferensiasi, adanya produk yang berkualitas, dan harga yang sesuai (Ratela \& Taroreh, 2016). Keputusan pembelian oleh konsumen terjadi karena adanya informasi yang disampaikan penjual (Anggraeni \& Madiawati, 2016) berupa komunikasi melalui promosi (Nurhayati, 2017) untuk menyampaikan adanya pilihan produk. Penyerapan informasi dari proses komunikasi melalui promosi mampu mempengaruhi konsumen 
dalam membuat keputusan memilih produk (Mulyanto, Ashanti, Andriyani, \& Nugroho, 2020). Persepsi promosi merupakan bagian dalam upaya memasarkan produk atau jasa dengan tujuan agar konsumen membeli atau mengkonsumsinya .

Kualitas Informasi sangat dibutuhkan saat akan berbelanja di toko online sehingga harus benar-benar diperhatikan. Semakin lengkap informasi yang disampaikan dan dapat diterima konsumen, semakin tertarik konsumen pada hal yang diinformasikan dan hal ini akan menguntungkan perusahaan. Kualitas informasi menjadi salah satu faktor terjadinya suatu transaksi keputusan pembelian (Anggraeni \& Madiawati, 2016). Informasi yang tidak berkualitas akan membingungkan konsumen dalam membuat keputusan pembelian. Bahkan terdapat temuan bahwa kualitas informasi tidak mempengaruhi keputusan konsumen dalam pembelian (Nazarudin \& Pela, 2016; Annisa, 2019).

Kesenjangan temuan dimana faktor kualitas informasi ada yang berpengaruh (Anggraeni \& Madiawati, 2016) dan ada yang tidak berpengaruh (Nazarudin \& Pela, 2016; Annisa, 2019) terhadap keputusan pembelian, menunjukkan adanya celah antara kualitas informasi dengan keputusan pembelian. Penelitian ini berupaya mengisi celah ini dengan menambahkan kepercayaan sebagai variabel mediasi dimana kepercayaan sangat dominan bagi konsumen dan merupakan dasar dalam membuat keputusan dalam membeli produk.

Kepercayaan muncul ketika konsumen mendapatkan kepastian dari pihak penjual, tercermin dari testimoni konsumen pada penelitian sebelumnya (Istiqomah, Hidayat, \& Jariah, 2019). Kepercayaan menjadi faktor penting dalam mempengaruhi keputusan pembelian seorang konsumen (Anggraeni \& Madiawati, 2016; Nawangsari \& Karmayanti, 2018; Solihin, 2020). Dilain pihak, kepercayaan dapat muncul karena persepsi konsumen atas promosi yang dialankan perusahaan (Nurbani, Mulyanto, Wardani, \& Andriyani, 2019). Kepercayaan konsumen juga dapat muncul manakala konsumen mendapatkan informasi yang berkualitas (Ferdiansyah \& Agus, 2019).

Keragaman produk yang bervariasi menjadi daya tarik untuk memenuhi kebutuhan konsumen karena konsumen akan memilih suatu produk yang dibutuhkannya (Rahmawati \& Nikmah, 2019). Keragaman produk secara langsung akan mempengaruhi keputusan konsumen dalam pembelian (Rifianita \& Basoeki, 2019).

Penelitian ini merupakan penyempurnaan dari beberapa penelitian sebelumnya. Penelitian berupaya menguji kepercayaan sebagai variabel pemediasi kualitas informasi dan promosi terhadap keputusan membeli dan menguji pengaruh keragaman produk terhadap keputusan membeli.

\section{Metodologi}

\subsection{Pengembangan Model}

\subsubsection{Keputusan Pembelian}

Proses pengambilan keputusan merupakan serangkaian urutan kegiatan individu dalam mendapatkan dan mempergunakan barang yang ditawarkan ketika membeli produk (Kotler \& Amstrong, 2008). Faktor keputusan pembelian antara lain informasi (Anggraeni \& Madiawati, 2016), promosi (Nurhayati, 2017; Mulyanto, Ashanti, Andriyani, \& Nugroho, 2020), pilihan produk (Rifianita \& Basoeki, 2019). 


\subsubsection{Kepercayaan dan Keputusan Pembelian}

Kepercayaan konsumen merupakan faktor penting dalam membangun hubungan dan adopsi pada e-commerce serta komitmen jangka panjang bagi perusahaan (Rehman, Shareef, \& Ishaque, 2012). Kompleksitas sebuah Kepercayaan memiliki variasi dari berbagai perspektif atau sudut pandang yang terkait ilmu psikologi, ekonomi, pemasaran, sosiologi dan politik (Lin, Wang, Wang, \& Lu, 2014).

Kepercayaan merupakan tergantungnya sebuah perusahaan kepada mitra bisnis atau pihak lain. Kepercayaan juga mempengaruhi berbagai pihak baik antar pribadi maupun antar organisasi. Kepercayaan terkait dengan kompetensi, kejujuran, kebaikan hati dan integritas (Kotler \& Keller, 2016). Kepercayaan dapat dibangun dalam sebuah situasi hal yang sulit, penerapan peraturan perusahaan yang ketat kepada mitra bisnis menjadikan mitra bisnis khawatir tidak mendapatkan produk dengan kualitas yang tepat. Kepercayaan sangat erat dengan suatu tindakan dari perilaku konsumen, semakin konsumen percaya maka semakin tinggi loyalitas konsumen (Anggraeni \& Madiawati, 2016; Nawangsari \& Karmayanti, 2018). Kepercayaan pelanggan (Solihin, 2020) mempunyai pengaruh pada keputusan pembelian (Sukma, 2012) .

\section{H1 : Kepercayaan berpengaruh terhadap Keputusan Pembelian}

\subsubsection{Promosi, Kepercayaan dan Keputusan Pembelian}

Promosi merupakan rangkaian strategi pihak penjual untuk mengkoordinasikan dan mengupayakan terciptanya berbagai saluran informasi yang terarah untuk menjual barang dan jasa dari sebuah ide awal (Morissan, 2010). Promosi yang menarik dan sesuai dengan fakta akan menambah kepercayaan konsumen kepada organisasi yang melakukan promosi tersebut (Wahyono \& Susilawati, 2016). Promosi dari penelitian sebelumnya berpengaruh terhadap kepercayaan dan berdampak pada keputusan mahasiswa memilih kuliah dengan hasil yang signifikan (Wahyono \& Susilawati, 2016).

\section{H2 : Promosi berpengaruh terhadap Kepercayaan}

\section{H3 : Promosi berpengaruh terhadap Keputusan melalui Kepercayaan}

\subsubsection{Kualitas Informasi, Kepercayaan dan Keputusan Pembelian}

Kualitas Informasi adalah manfaat yang dapat diperoleh dari sebuah kualitas. Kualitas informasi dapat berharga jika dibandingkan dengan biaya untuk memperolehnya. Tetapi informasi yang berkualitas sangat penting karena memiliki banyak kegunaan, sehingga tidak mungkin dapat menghubungkan antara informasi dengan suatu masalah. Semakin jelas suatu informasi yang diberikan akan spesifikasi produk maka semakin tinggi minat beli konsumen pada situs online (Sutabri, 2021). Semakin berkualitas sebuah informasi diterima konsumen, semakin tinggi kepercayaan dari konsumen sehingga berdampak pada keputusan pembelian (Gunawan \& Ayuningtiyas, 2018; Ferdiansyah \& Agus, 2019).

$H 4$ : Kualitas Informasi berpengaruh terhadap Kepercayaan

H5 : Kualitas Informasi berpengaruh terhadap Keputusan melalui Kepercayaan

\subsubsection{Keragaman Produk dan Keputusan Pembelian}

Keragaman produk adalah kesediaan semua jenis produk sekaligus banyaknya jumlah produk yang tawarkan dengan selera yang dibutuhkan konsumen yang dihasilkan oleh suatu produsen (Kotler \& Keller, 2016). Keberagaman produk terkait dengan variasi 
jenis dan ukuran produk yang bervariasi yang dijual pada marketplace untuk memenuhi kebutuhan konsumen. Banyaknya pilihan produk diharapkan menjadi daya tarik terendiri bagi konsumen untuk membeli kebutuhannya. Keragaman produk dari hasil strategi diferensiasi mempunyai pengaruh terhadap keputusan pembelian (Ratela \& Taroreh, 2016; Rifianita \& Basoeki, 2019).

H6 : Keragaman produk berpengaruh terhadap Keputusan Pembelian

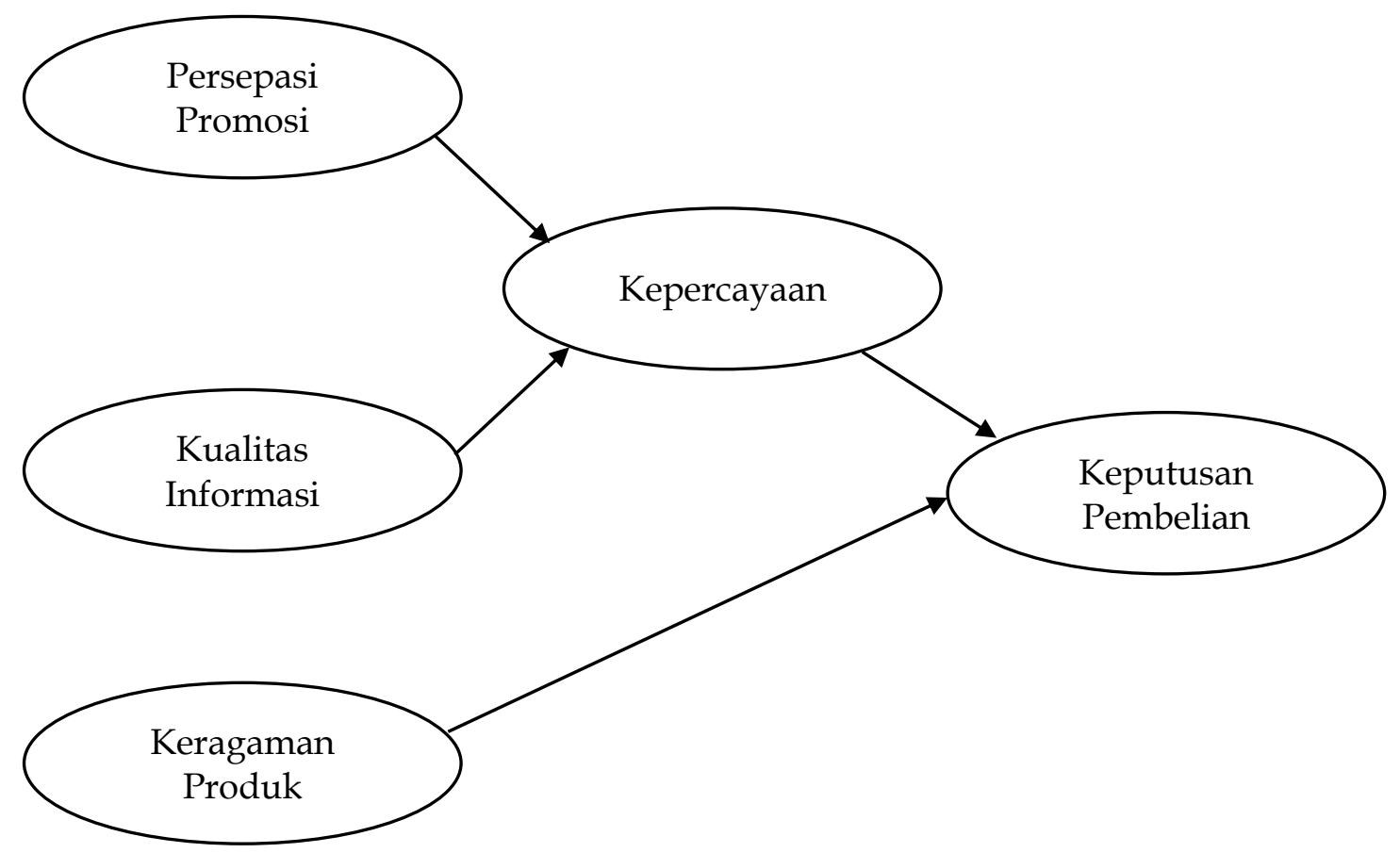

Sumber: Pengembangn model, 2020

\section{Gambar 1. Desain Penelitian}

\subsection{Pengumpulan Data}

Data diperoleh dari kuesioner tertutup dalam jangka waktu satu bulan. Sedangkan untuk populasi penelitian ini adalah pelanggan Tokopedia di Kab. Bekasi. Jumlah sampel penelitian adalah 106 responden menggunakan metode ML (Maximun Likehood) yaitu minimal 5 data/sampel. Pengambilan sampel yang digunakan dalam penelitian ini adalah non probability sampling dengan pendekatan purposive sampling (Mulyanto \& Wulandari, 2010).

\subsection{Metode Analisis}

Structural Equation Modeling (SEM) menggunakan metode Partial Least Square (PLS) dipilih karena bersifat predictive (Ghozali \& Latan, 2015). Analisis diawali dengan pengujian outer loading dengan kriteria lebih dari 0,7 sebagai uji validitas sekaligus composite reliability dan cronbach's alpha untuk uji reliabilitas. Langkah berikutnya adalah pemeriksaan model dengan R Square dan diakhiri dengan uji hipotesis berdasar nilai path koefisien. 


\section{Hasil}

\subsection{Responden}

Data penelitian diperoleh dari 106 pemakai atau konsumen dari aplikasi tokpedia dengan karakteristik yang dirangkum pada tabel 2.

Tabel 2. Data Responden

\begin{tabular}{ccc}
\hline \multicolumn{1}{c}{ Variabel } & Jumlah & Persen \\
\hline Jenis Kelamin & & \\
$-\quad$ Perempuan & 58 & 54,7 \\
$-\quad$ Laki-laki & 48 & 45,3 \\
\hline Usia & & \\
$-\quad$ 18-25 Tahun & 67 & 63,2 \\
$-\quad$ 26-35 Tahun & 39 & 35,8 \\
\hline Status & & \\
- Lajang & 82 & 77,4 \\
- Sudah Menikah & 24 & 22,6 \\
\hline Pekerjaan & & \\
- Karyawan Swata & 76 & 67,0 \\
- PNS/ASN & 2 & 1,9 \\
- Pelajar/Mahasiswa & 14 & 13,2 \\
- Lainnya & 14 & 13,2 \\
\hline
\end{tabular}

Sumber: Data hasil kuesioner yang diolah, 2021

Tabel 2 menunjukkan data responden yaitu pelanggan dari pemakai aplikasi tokopedia sebanyak 106 orang. Sebagian besar responden Perempuan, berusia rentang 18 - 25 tahun, berstatus lajang, dan pekerjaan karyawan swasta.

\subsection{Analisis}

Hasil pengujian outer yang digunakan untuk pengujian validitas dan reliabilitas disajikan pada tabel 3. Hampir seluruh indikator pada setiap variabel telah valid karena telah lebih besar daripada 0,7. Seluruh variabel juga telah reliabel karena telah memenuhi cut off yang digunakan dalam penelitian ini (cronbach alpha persepsi promosi 0,871; kualitas informasi 0,867; keragaman produk 0,899; kepercayaan 0,847 dan keputusan pembelian 0,901 lebih besar dari 0,7 sedangkan composite reliability persepsi promosi 0,876; kualitas informasi 0,918; keragaman produk 0,926; kepercayaan 0,908 dan keputusan pembelian 0,927 lebih besar daripada 0,8).

Model dapat diterima karena seluruh variabel endogen memiliki nilai $\mathrm{R}$ square lebih besar dari 0,2. Variabel endogen Kepercayaan memiliki nilai $R$ square 0,630 atau dalam kategori sedang dan sedangkan variabel endogen Keputusan Pembelian dengan nilai $\mathrm{R}$ square 0,519 dalam kategori sedang juga.

Gambar 1 menunjukkan estimasi dari indikator ke variabel dan keterkaitan antar variabel. Seluruh indikator telah berkontribusi membentuk variabel masing-masing. Indikator $\mathrm{P}$ merupakan indikator utama pembentuk persepsi promosi, KI sebagai indikator utama kualitas informasi, KBP merupakan indikator utama pembentuk 
keragaman produk, KPR merupakan indikator utama pembentuk kepercayaan dan KP merupakan indikator utama dari keputusan pembelian.

Tabel 3. Outer Model

\begin{tabular}{ccccc}
\hline Variabel/Indikator & $\begin{array}{c}\text { Outer } \\
\text { Loading }\end{array}$ & $\begin{array}{c}\text { Crombah } \\
\text { Alpha }\end{array}$ & $\begin{array}{c}\text { Composite } \\
\text { Reliability }\end{array}$ & $\begin{array}{c}\text { Kesimpula } \\
\mathrm{n}\end{array}$ \\
\hline Persepsi Promosi & & 0.871 & 0,876 & Reliabel \\
- Periklanan & 0,753 & & & Valid \\
- Penjualan pribadi & 0,825 & & & Valid \\
- Promosi penjualan & 0,758 & & & Valid \\
- Pemasaran langsung & 0,882 & & & Valid \\
- Publisitas & 0,841 & & & Valid \\
\hline Kualitas Informasi & & 0,867 & 0,918 & Reliabel \\
- Akurat & 0,908 & & & Valid \\
- Ketepatan waktu & 0,894 & & & Valid \\
- Relevansi & 0,862 & & & Valid \\
\hline Keragaman Produk & & 0,899 & 0,926 & Reliabel \\
- Ukuran produk & 0,842 & & & Valid \\
- Jenis produk & 0,905 & & & Valid \\
- Bahan produk & 0,791 & & & Valid \\
- Desain produk & 0,826 & & & Valid \\
- Kualitas produk & 0,857 & & & Valid \\
\hline Kepercayaan & & 0,847 & 0,908 & Reliabel \\
Jaminan kepuasan & 0,876 & & & Valid \\
- Perhatian & 0,897 & & & Valid \\
- Keterus-terangan & 0,852 & & & Valid \\
\hline Keputusan Pembelian & & 0,901 & 0,927 & Reliabel \\
- Memilih Produk & 0,841 & & & Valid \\
- Memilih Merek & 0,815 & & & Valid \\
- Metode pembayaran & 0,846 & & & Valid \\
- Memilih Penyalur & 0,884 & & & Valid \\
- Waktu Pembelian & 0,846 & & & \\
\hline
\end{tabular}

Sumber: Hasil Pengolahan, 2021

Tabel 4. Indeks Pengujian Model

\begin{tabular}{lllcc}
\hline Endogenous Variabel & $\begin{array}{c}\text { Cut of } \\
\text { Value }\end{array}$ & $\begin{array}{c}\text { Hasil } \\
\text { Analisis }\end{array}$ & Evaluasi model \\
\hline $\mathrm{R}^{2}$ & & & & \\
& & & & \\
- & Kepercayaan & 0,20 & 0,630 & Fit \\
$-\quad$ Keputusan Pembelian & $\geq 0,20$ & 0,519 & Fit \\
\hline
\end{tabular}

Sumber: Data Primer yang diolah, 2021 


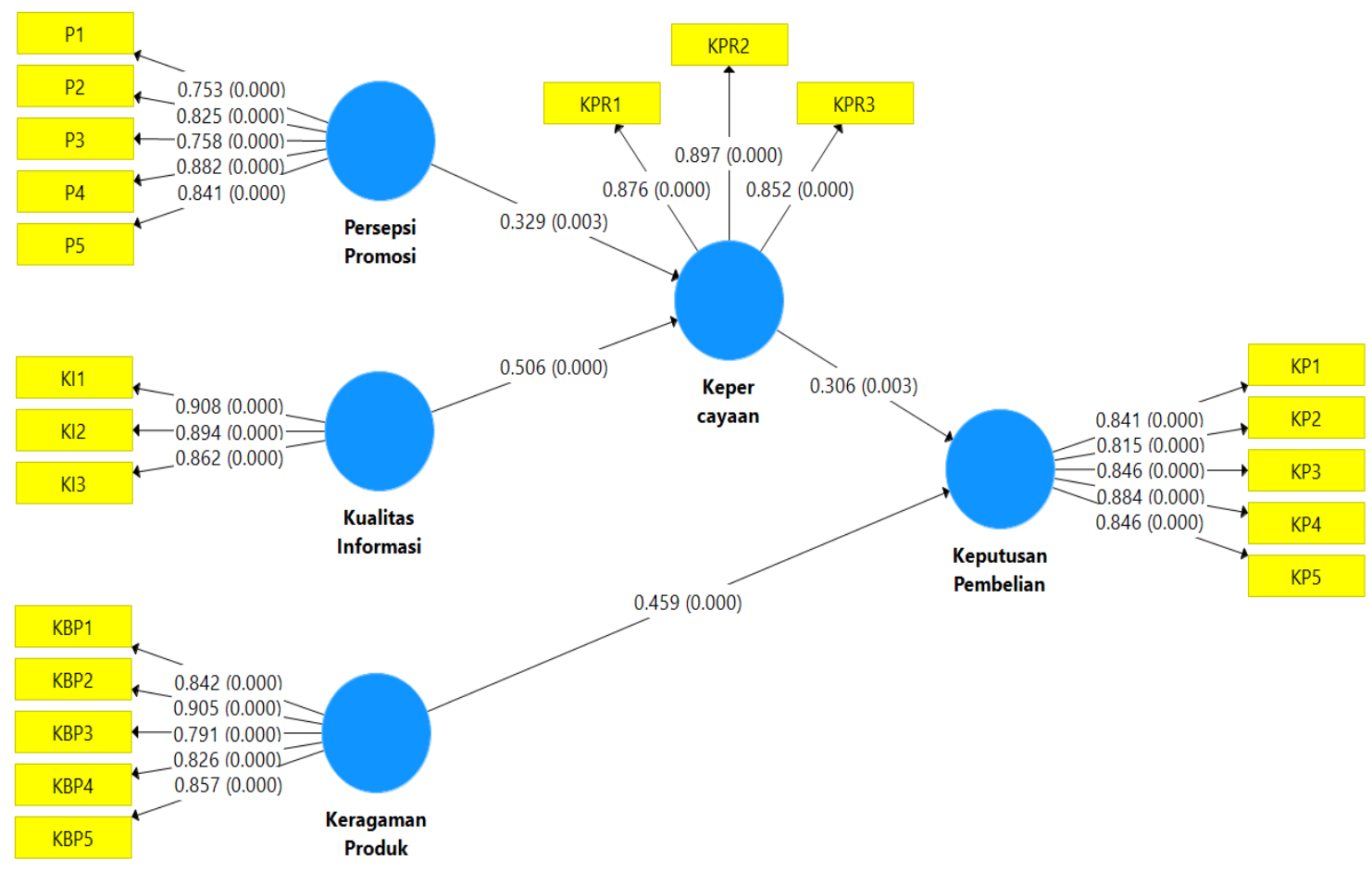

Sumber: Olah data, 2021

Gambar 1. Hasil Analisis

Tabel 5. Estimasi

\begin{tabular}{|c|c|c|c|c|}
\hline Alur & Jenis & $\begin{array}{c}\text { Std. } \\
\text { Estimates }\end{array}$ & P-Value & Kesimpulan \\
\hline $\begin{array}{l}\text { Kepercayaan } \rightarrow \text { Keputusan } \\
\text { Pembelian }\end{array}$ & Langsung & 0,306 & 0,003 & Signifikan \\
\hline $\begin{array}{l}\text { Keragaman Produk } \rightarrow \text { Keputusan } \\
\text { Pembelian }\end{array}$ & Langsung & 0,459 & 0,000 & Signifikan \\
\hline Kualitas Informasi $\rightarrow$ Kepercayaan & Langsung & 0,506 & 0,000 & Signifikan \\
\hline Persepsi Promosi $\rightarrow$ Kepercayaan & Langsung & 0,329 & 0,003 & Signifikan \\
\hline $\begin{array}{l}\text { Kualitas Informasi } \rightarrow \text { Kepercayaan } \rightarrow \\
\text { Keputusan Pembelian }\end{array}$ & $\begin{array}{c}\text { Tidak } \\
\text { Langsung }\end{array}$ & 0,155 & 0,013 & Signifikan \\
\hline $\begin{array}{l}\text { Persepsi Promosi } \rightarrow \text { Kepercayaan } \rightarrow \\
\text { Keputusan Pembelian }\end{array}$ & $\begin{array}{c}\text { Tidak } \\
\text { Langsung }\end{array}$ & 0,101 & 0,046 & Signifikan \\
\hline
\end{tabular}

Sumber: Data penelitian yang diolah, 2021

Tabel 5 menunjukkan pengaruh dan signifikansi antar variabel. Kepercayaan dan keberagaman produk berpengaruh terhadap keputusan pembelian, kualitas informasi dan persepsi promosi berpengaruh terhadap kepercayaan. Kepercayaan memediasi kualitas informasi dan persepsi promosi terhadap keputusan pembelian. 


\section{Pembahasan}

\subsection{Pengaruh Kepercayaan Terhadap Keputusan Pembelian}

Penelitian menghasilkan temuan bahwa kepercayaan yang digunakan pada platform konsumen aplikasi tokopedia berpengaruh positif terhadap keputusan pembelian sebesar 0,306 . Semakin baik jaminan kepuasan yang diterapkan pada platform aplikasi tokopedia akan mendorong tumbuhnya kepercayaan konsumen terhadap tokopedia. Dengan kata lain kepercayaan yang meningkat baik secara kualitas maupun kuantitas akan mendorong konsumen untuk terus menggunakan Tokopedia seterusnya.

Penelitian ini sejalan dengan temuan sebelumnya, bahwasannya konsumen dengan kepercayaan yang tinggi akan membuat konsumen cepat dalam mengambil keputusan (Anggraeni \& Madiawati, 2016; Nawangsari \& Karmayanti, 2018). Kepercayaan pelanggan (Solihin, 2020) mempunyai pengaruh pada keputusan pembelian (Sukma, 2012) .

\subsection{Pengaruh Persepsi Promosi Terhadap Kepercayaan dan Keputusan Pembelian}

Penelitian menghasilkan temuan bahwa persepsi promosi yang digunakan pada platform konsumen aplikasi tokopedia berpengaruh positif terhadap kepercayaan sebesar 0,329. Semakin baik periklanan yang diterapkan pada platform aplikasi tokopedia akan mendorong tumbuhnya kepercayaan konsumen terhadap tokopedia. Dengan kata lain persepsi promosi yang meningkat baik akan mendorong konsumen untuk terus percaya terhadap aplikasi Tokopedia.

Persepsi promosi dalam penelitian ini berpengaruh secara tidak langsung melalui kepercayaan dengan arah positif sebesar 0,155. Hasil ini semakin menguatkan pentingnya kepercayaan sebagai penghubung persepsi promosi dan keputusan pembelian. Peran kepercayaan semakin terlihat mengingat pengaruh persepsi promosi terhadap keputusan pembelian lebih rendah dibandingkan pengaruh kepercayaan terhadap keputusan pembelian.

Terdapat temuan menarik bahwa persepsi promosi secara tidak langsung dapat mendorong keputusan pembelian. Temuan ini mengkonfirmasi dan menguatkan temuan sebelumnya bahwa persepsi promosi tidak secara langsung mempengaruhi keputusan pembelian (Wahyono \& Susilawati, 2016; Wahyono \& Susilawati, 2016)..

\subsection{Pengaruh Kualitas Informasi Terhadap Kepercayaan dan Keputusan Pembelian}

Penelitian menghasilkan temuan bahwa kualitas informasi yang digunakan pada platform konsumen aplikasi tokopedia berpengaruh positif terhadap kepercayaan sebesar 0,506. Semakin akurat kualitas informasi yang diterapkan pada platform aplikasi tokopedia akan mendorong tumbuhnya kepercayaan konsumen terhadap tokopedia. Dengan kata lain kualitas informasi yang meningkat baik akan mendorong konsumen untuk terus percaya terhadap aplikasi Tokopedia.

Penelitian berbeda dengan hasil (Nazarudin \& Pela, 2016) yang menyatakan kualitas informasi tidak berpengaruh signifikan terhadap keputusan pembelian. Penelitian ini sejalan dengan temuan sebelumnya, bahwasanya kualitas informasi mempunyai pengaruh terhadap kepercayaan dan keputusan memilih meskipun dalam konteks dan 
pengukuran yang berbeda (Wahyono \& Susilawati, 2016). Terdapat temuan menarik bahwa kualitas informasi secara tidak langsung dapat mendorong keputusan pembelian. Temuan ini mengkonfirmasi dan menguatkan temuan sebelumnya bahwa kualitas informasi secara tidak langsung mempengaruhi keputusan pembelian (Anggraeni \& Madiawati, 2016)

Kualitas informasi dalam penelitian ini berpengaruh secara tidak langsung melalui kepercayaan dengan arah positif sebesar 0,101. Hasil ini semakin menguatkan arti penting kepercayaan sebagai penghubung kualitas informasi dan keputusan pembelian. Peran kepercayaan semakin terlihat mengingat pengaruh kualitas informasi terhadap keputusan pembelian lebih kuat dibandingkan pengaruh kualitas informasi terhadap keputusan Pembelian secara langsung.

\subsection{Pengaruh Keragaman Produk Terhadap Keputusan Pembelian}

Penelitian menghasilkan temuan bahwa keragaman produk yang digunakan pada platform konsumen aplikasi tokopedia berpengaruh positif terhadap keputusan pembelian sebesar 0,456 . Semakin banyak jenis produk yang diaplikasikan di platform aplikasi tokopedia akan mendorong tumbuhnya konsumen untuk membeli produk di tokopedia. Dengan kata lain keragaman produk yang bervariasi atau banyak jenisnya akan mendorong konsumen untuk terus menggunakan Tokopedia seterusnya.

Penelitian ini sejalan dengan temuan sebelumnya, bahwasannya keragaman produk mempunyai pengaruh terhadap keputusan pembelian meskipun dalam konteks dan pengukuran yang berbeda (Rifianita \& Basoeki, 2019; Ratela \& Taroreh, 2016).

\section{Kesimpulan}

Kepercayaan dan Keragaman Produk berpengaruh signifikan terhadap Keputusan Pembelian; Persepsi Promosi, dan Kualitas Informasi terhadap Kepercayaan signifikan juga pengaruhnya; Persepsi Promosi dan Kualitas informasi berpengaruh signifikan secara tidak langsung yang di mediasi oleh Kepercayaan.

Penelitian berikutnya perlu berupaya untuk menambahkan variabel penelitian baik sebagai pemediasi ataupun pemoderasi. Penelitian lanjutan diperlukan dengan jalan menggunakan obyek dan pengukuran yang lebih sesuai dengan obyek yang diteliti.

\section{Daftar Pustaka}

A. Sukma. (2012). Analisis Faktor-Faktor yang Mempengaruhi Keputusan Pembelian melalui Social Networking Website. Jurnal Ekonomi Manajemen, 1-11.

Anggraeni, P., \& Madiawati, P. N. (2016). Pengaruh Kepercayaan dan Kualitas Informasi Terhadap Keputuan Pembelian Secara Online pada Situs www.traveloka.com. $e^{-}$ Proceeding of Management, 3(2), 1 - 8.

Annisa, D. (2019). Pengaruh Kepercayaan, Kemudahan dan Kualitas Informasi Terhadap Keputusan Pembelian Online Melalui Aplikasi Shopee (Studi Kasus PadaMahasiswa Ilmu Komunikasi UniversitasMulawarman 2015-2017). eJournalAdministrasi Bisnis, 7(1), 248 - 261. Retrieved from ejournal.adbisnis.fisipunmul.ac.id

Ferdiansyah, G., \& Agus, R. (2019, 11 18). Pengaruh Kualitas Informasi Terhadap Keputusan Pembelian Secara Online Yang dimediasi Kepercayaan Konsumen 
(Survei pada Pengguna E-commerce di Indonesia). Journal of Business Management Education (JBME), 2(1), 17 - 20. doi:10.17509/jbme.v2i2.5975

Ghozali, I., \& Latan, H. (2015). Partial Least Squares Konsep, Teknik dan Aplikasi Menggunakan Program SmartPLS 3.0. Semarang: Badan Penerbit.

Gunawan, H., \& Ayuningtiyas, K. (2018). Pengaruh Kepercayaan, Kemudahan Dan Kualitas Informasi Terhadap Keputusan Pembelian Daring Di Aplikasi Bukalapak Pada Mahasiswa Politeknik Negeri Batam. Journal of Applied Business Administration, 2(1), 152 - 165. doi:https:// doi.org/10.30871/jaba.v2i1.763.

Istiqomah, Hidayat, Z., \& Jariah, A. (2019, July). Analisis Pengaruh Kepercayaan , Iklan Dan Persepsi Resiko Terhadap Keputusan Pembelian Di Situs Shopee Di Kota Lumajang., 2, pp. 557 - 563.

Jurnal.id. (2019). Retrieved from https://www.jurnal.id/id/blogstrategi-pemasarantepat.pdf.

Kotler, P., \& Keller, L. (2016). Marketing Managemen, 15th Edition. Pearson Education,Inc. Kotler, P., \& Amstrong, G. (2008). Prinsip-prinsip Pemasaran. Jakarta: Erlangga.

Lin, J., Wang, B., Wang, N., \& Lu, Y. (2014). Understanding the Evolution of Consumer Trust in Mobile Commerce: A Longitudinal Study. Information Technology and Management, 15(1), 37 - 49. doi:https:/ / doi.org/10.1007/s10799-013-0172-y.

Morissan, A. M. (2010). Periklanan Komunikasi Pemasaran Terpadu. Jakarta: Kencana.

Mulyanto, H., \& Wulandari, A. (2010). Penelitian: Metode dan Analisis. Semarang: CV Agung.

Mulyanto, H., Ashanti, A., Andriyani, M., \& Nugroho, A. T. (2020, Desember). Loyalitas Mahasiswa: Dampak Persepsi Bauran Komunikasi Terhadap Proses Keputusan Memilih Perguruan Tinggi. Jurnal Manajemen Kewirausahaan, 17(2), 107 - 116. doi:http://dx.doi.org/10.33370/jmk.v17i2.485

Nawangsari, S., \& Karmayanti, Y. (2018). Pengaruh Kepercayaan, Kemudahan, Dan Kualitas Informasi Terhadap Keputusan Pembelian Melalui Media Sosial Instagram (Study Kasus pada Online Shop YLK.Store). Konferensi Nasional Sistem Informasi 2018, STMIK Atma Luhur Pangkalpinang, 8 - 9 Maret 2018 (pp. 61 - 67). Pangkal Pinang: STIMIK Atma Luhur Pangkalpinang.

Nazarudin, H., \& Pela, Y. (2016). Pengaruh Kemudahan dan Kualitas Informasi Terhadap Keputusan Pembelian Secara Online di Situs D'BC Network Orifline (Studi Pada Masyarakat Fatufeto Kota Kupang). Jurnal Bisnis \& Manajemen, 2(2), 112 - 134.

Nurbaeni, A., Mulyanto, H., Wardani, M. K., \& Andriyani, M. (2019, Desember). Pengaruh Bauran Pemasaran Terhadap Kepuasan dan Kepercayaan Serta Dampaknya pada Loyalitas Konsumen. Jurnal Manajemen Kewirausahaan, 16(2), 109 - 120. doi:http:/ / dx.doi.org/10.33370/jmk.v16i2.346

Nurhayati, Siti. (2017). Pengaruh citra merek, harga dan promosi terhadap keputusan pembelian handphone samsung di yogyakarta. JBMA - Vol. IV, No. 2, September 2017 ISSN : 2252-5483, 60-69.

Rahmawati, L., \& Nikmah, F. (2019). Pengaruh Kepercayaan dan Kualitas Informasi Terhadap Keputusan Pembelian Secara Online Di Shopee. Jurnal Aplikasi Bisnis (JAB), 125-128.

Ratela, G. D., \& Taroreh, R. (2016). Analisis Strategi Diferensiasi, Kualitas Produk dan Harga Terhadap Keputusan Pembelian di Rumah Kopy Coffee Island. Jurnal EMBA, 4(1), 460 - 471.

Rehman, S. U., Shareef, A., \& Ishaque, A. (2012). Situational and Enduring Involvement: Impact on Relationship Marketing Tactics. Interdisciplinary Journal of Contemporary Research in Business, 4(1), 598 - 605. 
Rifianita, R. D., \& Basoeki, R. S. (2019). Pengaruh Store Layout dan Keragaman Produk Terhadap Keputusan Pembelian (Studi Kasus pada Seamart Swalayan Malang). J A B Jurnal Aplikasi Bisnis, 5(3), 113 - 116.

Schiffman, L., \& Kanuk, L. (2010). Schiffman, L.G., \& Kanuk, L.L. (2010). Consumer Behaviour (10th ed). New Jersey, Pearson Prentice. New Jersey: Pearson Prentice.

Solihin, D. (2020). Pengaruh Kepercayaan Pelanggan dan Promosi Terhadap Keputusan Pembelian Konsumen Pada Online Shop Mikaylaku Dengan Minat Beli Sebagai Variabel Intervening. JURNAL MANDIRI: Ilmu Pengetahuan, Seni, dan Teknologi, 4(1), 38 - 51. doi:DOI : https:/ / doi.org/10.33753/mandiri.v4i1.99

Sukma, A. A. (2012). Analisis Faktor-Faktor yang Mempengaruhi Keputusan Pembelian Melalui Sosial Networking Website. Jurnal Ekonomi Manajemen, 1 - 11.

Sutabri, T. (2021). Konsep Sistem Informasi. Yogyakarta: Andi.

Wahyono, S. A., \& Susilawati. (2016). Pengaruh Bauran Promosi Terhadap Kepercayaan dan Dampaknya Terhadap Keputusan Mahasiswa Memilih Kuliah (StudiKasus Politeknik LPKIA Kota Bandung). Jurnal Indonesia Membangun, 15(2), 82 - 100.

www,inet.detik.com. (2021). Retrieved from https://inet.detik.com/cyberlife/d5469818/tokopedia-e-commerce-yang-paling-banyak-dikunjungi-pada-januari2021

www.akseleran.co.id. (2020). Retrieved from https://www.akseleran.co.id/blog/perkembangan-teknologi.pdf.

www.tekno.kompas.com. (2021). Retrieved from https://tekno.kompas.com/read/2021/02/23/16100057/jumlah-penggunainternet-indonesia-2021-tembus-202-juta 